\title{
Characterization Of Coal Acid Water In Void Pools Of Coal Mining In South Kalimantan
}

\author{
Kiswanto $^{1}$, Heru Susanto ${ }^{2}$, Sudarno ${ }^{3}$ \\ ${ }^{1}$ Doctoral Program of Environmental Studies, School of Postgraduate Studies, Diponegoro University, Semarang Indonesia \\ ${ }^{2}$ Study Program of Chimical Engering Studies, Diponegoro University, Jl. Prof. H. Soedharto, S.H, Tembalang Semarang Indonesia \\ ${ }^{3}$ Doctoral Program of Environmental Science, School of Postgraduate Studies, Diponegoro University, Semarang Indonesia
}

\begin{abstract}
This study aims to determine the characteristics of acidic water derived from void coal mine by taking samples from voids located in South Kalimantan. Method used in this research was field work and laboratory work. The result of measurement of acid characterization of coal mine acid was analyzed to have the highest $\mathrm{pH}$ value of 4.01, the highest temperature was $33.9^{\circ} \mathrm{C}$, the highest Color was $3.01 \mathrm{NTU}$, the highest COD was $56.50 \mathrm{ppm}$, the highest BOD was 20,34 ppm, The highest DHL of 1 us, the highest TSS of $652.67 \mathrm{ppm}$, the highest Fe of $9.46 \mathrm{ppm}$, the highest Mn of 1.72 ppm and the Cd content is still below the defined standard of less than $0.01 \mathrm{ppm}$. Decree of the State Minister of Environment No. 113 of 2003 on Liquid Waste Quality Standards for Coal Mining.
\end{abstract}

Keywords: Acidic water, Characterization,Coal

\section{Introduction}

Coal mining now has an impact on the damage to the surrounding environment. One of the impacts of the coal mining process is the emergence of acid mine drainage. The emergence of acid mine water has a great impact on the preservation of the environment and the surrounding community either directly or indirectly. Acid water is affected by three main factors: water, air and materials containing sulphide minerals.Run-off when the mine drainage has the potential to pollute the body of natural waters either in the form of acidic mine water or not acid mine water if it is not managed and controlled properly. Good mine water management includes the control of water quantity (pumps and piping systems) and water quality.

The former coal mining area that has been flooded water will become a giant pool that forms a basin. The former coal mine pool will be formed when the rainy season arrives. When the rainy season the peat soil and the remnants of coal mining will be dissolved in it. The impact of water in a pool of former coal will become acidic.

This former coal mining pond (Void) in South Kalimantan is located not far from the stockpile of coal potentially affecting the quality of the surrounding environment. When the wet season comes the wastewater from coal stockpiles participated dissolved and entered into the pool of former coal mines and some solutes inside. In order not to pollute the environment, the liquid waste must be processed first before discharge into the environment. Liu, H. F. D, (1999) states that an important step in the treatment of liquid waste is to know the characteristics of liquid waste[12].
This study presents the results of acid characterization of coal mine water and the measurement of acidic water in a pool of former coal mines. Testing of acid quality of coal mine water conducted at pit 1, pit 2 and pit 3 of coal mine in South Kalimantan aims to find out the karkaterisastik water originating from the former void mine. The existence of acidic characteristics of coal mine data as a benchmark for prevention and processing. So that the processing process can reduce low carbon for sustainable development.

\section{Methodology}

\subsection{Research methods}

Research methods used in field surveys and laboratory tests. Field surveys were carried out by taking acid water from coal pools. Parameters measured $\mathrm{pH}$, Temperature, Color, COD, BOD, DHL, TSS, Fe, Mn and Cd were performed in the Environmental Science Laboratory of Diponegoro University.

\subsection{Tools and materials}

Tools used include $\mathrm{pH}$ meter, sample bottle, cool box, label paper, oven, desiccator, balance sheet, measuring glass, beaker, filter paper, and Atomic Absorption Spectrophotometer (SSA). The materials used are Buffer 3 solution, Digestion solution, sulfuric acid reagent Buffer 10 solution, Aquadest, and blank solution. 


\subsection{Research procedure}

The samples of acidic coal water were taken from several pools of former coal mines by means of instantaneous sampling (grab samples). Measurement parameters of liquid waste include $\mathrm{pH}$, Temperature, Color, COD, BOD, DHL, TSS, Fe, Mn and Cd

\subsection{Data analysis}

Data obtained from coal acid water measurements were analyzed descriptively. The result of measurement of $\mathrm{pH}$, Temperature, Color, COD, BOD, DHL, TSS, Fe, $\mathrm{Mn}$ and $\mathrm{Cd}$ parameters found in liquid wastewater also compared with liquid waste quality standard based on Decree of State Minister of Environment no. 113 of 2003 on Liquid Waste Quality Standard for Coal Mining[9].

\section{Results and Discussion}

Testing of acid water quality of coal mine conducted at void 1 , void 2 and void 3 location of coal mine in South Kalimantan to know karkaterisastik water from coal mine whether existing water treatment has been able to perform its function properly or not.

Testing the quality of acid mine coal water in void 1 , void 2 and void 3 ex-coal mine was done to know the characterization of $\mathrm{pH}$, Temperature, Color, COD, BOD, DHL, TSS, Fe, Mn and Cd which play a role in acidic coal water in ponds. Acid water is produced from rainwater runoff carrying fine particles of coal. These fine particles are then soluble and mixed with organic matter in void 1 , void 2 and void 3 of the former coal mines. Characterization test of acid water in mine pond was analyzed in three pools of former coal mine, namely void 1 , void 2 and void 3 . Kegitan characterization analysis in three pits of coal mine will be seen on $\mathrm{pH}$, Temperature, Color, COD, BOD, DHL, TSS, Fe, Mn and $\mathrm{Cd}$.

Table 1. Result of Quality Test of Liquid Acid Liquid Waste

\begin{tabular}{llllll}
\hline No & Parameter & Unit & $\begin{array}{l}\text { Void } \\
1\end{array}$ & $\begin{array}{l}\text { Void } \\
2\end{array}$ & Void 3 \\
\cline { 3 - 6 } & & & & & \\
\hline 1. & pH & - & 4,01 & 4,50 & 4,75 \\
2. & Temperature & ${ }^{0} \mathrm{C}$ & 25 & 33,9 & 32 \\
3. & Color & NTU & 3,01 & 0,00 & 0,23 \\
4. & COD & ppm & 56,50 & 15,7 & 3,92 \\
5. & BOD & ppm & 20,34 & 5,49 & 1,37 \\
6. & DHL & us & 1 & 1 & 1 \\
7. & TSS & ppm & 62 & 320 & 652,67 \\
8. & Fe & ppm & 5,408 & 8,05 & 9,46 \\
9. & Mn & ppm & 1,172 & 1,25 & 1,24 \\
10. & Cd & ppml & $<, 01$ & $<0,01$ & $<0,01$ \\
\hline
\end{tabular}

\section{$3.1 \mathrm{pH}$}

The $\mathrm{pH}$ value in acidic coal water is caused by stripping of soil cover, coal excavation, and waste material causing exposure of soil / rock containing sulphide minerals, such as Pirit (Pyrite) and Markasit (Marcasite). The sulphide mineral then reacts with the oxidant and water to form acid mine water:

$2 \mathrm{FeS}+7 \mathrm{O} 2+2 \mathrm{H} 2 \mathrm{O} \rightarrow 2 \mathrm{Fe} 2++\mathrm{SO} 42-+4 \mathrm{H}+$

Thus, in addition to being characterized by low $\mathrm{pH}$, mine acid water will also contain metals with high concentrations of this, in line with the metallic analysis results in the inlet much larger than the outlet concentration, which can adversely affect both environmental and human health[13].

The $\mathrm{pH}$ value or degree of acidity indicates acid or base content in a solution. $\mathrm{pH}$ is a term for expressing the intensity of the alkaline or acidic state of something through hydrogen ions or $\left(\mathrm{H}^{+}\right)$levels. Hydrogen ions are the main factor for knowing chemical reactions. Hydrogen ions always exist in dynamic equilibrium with water, forming the atmosphere for all chemical reactions related to water pollution problems. Normal $\mathrm{pH}$ values are approximately neutral between $\mathrm{pH} 6-8$. The $\mathrm{pH}$ of wastewater differs depending on the type of effluent. The $\mathrm{pH}$ value is one of the major limiting factors for the survival of aquatic biota[11]. In the treatment of liquid waste, $\mathrm{pH}$ also has an important role to reduce contaminants in it [4]. Changes in acidity in wastewater to either alkaline or acidic $(\mathrm{pH})$ decreases will greatly disrupt the life of aquatic biota and the surrounding environment. Decreasing the $\mathrm{pH}$ value will magnify the corrosive properties. High acidity levels will also dissolve heavy metals so as to increase metal solubility[2]. From the analysis of the quality of waste water in the pool of coal mining formerly found that the $\mathrm{pH}$ value in void 1 amounted to 4.010 , void 2 of 4.5 and void 3 of 4.75. In general, the $\mathrm{pH}$ values in these three voids are at acidic $\mathrm{pH}$ values, thus exceeding the standard quality threshold.

\subsection{Temperature}

Acidic mine temperature will affect the recipient's body when there is a large temperature difference. Temperature can also affect the speed of chemical reactions and life of aquatic biota. Changes in temperature indicate the chemical and biological activity of solids, gases in water

It is a very important parameter because of its effects on chemical reactions, reaction rates, the life of aquatic organisms and the use of water for various daily activities.At high temperatures decay occurs and the addition of oxidation levels of organic matter. there is lubanng pond former coal mine has water temperature at void 1 equal to $25^{\circ} \mathrm{C}$, void 2 equal to $33,9^{\circ} \mathrm{C}$ and at void 3 equal to $32{ }^{\circ} \mathrm{C}$. Of the three voids that the highest acid water temperature on void 2 is $33.9^{\circ} \mathrm{C}$. Because in void 2 a lot of waste discharges that affect the temperature changes in acid water. 


\subsection{Color}

Color is one of the physical parameters of wastewater that can be observed directly, but not a priority. Color arises from the presence of a solute or suspended in water, in addition to a particular dye containing heavy metals. Colors that exist in pond hole former coal mine on void 1 , void 2 and void 3 colored rather bright and bright. This is because the process of boremediation in the three voids is running well. turbidity occurs during the rainy season. Turbidity is strongly influenced by the presence of suspended materials such as sand, mud, organic and inorganic materials, plankton and other microscopic organisms. This can disrupt the ecological balance of a habitat because it can reduce the penetration of incoming sunlight. The result of measurement of turbidity value at color value on void 1 is 3.01 , void 2 ; 0.00 and void $3 ; 0.23$. This indicates that the color of mine acid water is very bright even in void 2 indicating excellent brightness, this happens sedimentation and the presence of some plants in ponds of former coal mines helps in the process of bioremediation and phytoremediation.

\subsection{COD (Chemical Oxygen Demand)}

COD was the amount of oxygen demand in water for chemical reaction process to describe the contaminants. Measurement of waste strength with COD is another form of measurement of oxygen demand in wastewater. This measurement emphasizes the need for chemical oxygen in which the compounds being measured are materials that can not be split biochemically. The value of COD in uncontaminated waters is usually less than 20 $\mathrm{mg} / 1$. This if the let continuously and meniningkat can cause water biota to die. Sempel fat and oil showed no increase or decrease [19].

The COD figure is a measure for water contamination by inorganic substances. In the laboratory, the measurement of COD is done instantly by making the oxidizing $\mathrm{K} 2 \mathrm{Cr} 2 \mathrm{O} 7$ used as the source of oxygen. Based on the results of the analysis of laboratory tests obtained COD on void 1 with a value of $56.50 \mathrm{ppm}$, void 2 with a value of $15.69 \mathrm{ppm}$, and on void 3 with a value of $3.93 \mathrm{ppm}$. The lowest COD is in void 3 , it is because the void 3 has been carried out by bioremediation and phytoremediation processes so that there is a decrease in the COD value during the deposition process..

\subsection{BOD (Biochemical Oxygen Demand)}

BOD was a measure of the content of organic matter in liquid waste. BOD is determined by measuring the amount of oxygen absorbed by the liquid waste sample due to microorganisms over a given period of time [16]. High BOD values indicate poor water quality. BOD can be received when the amount of oxygen to be spent in five days by aerobic decomposition organisms in the volume of waste at $200{ }^{\circ} \mathrm{C}$. The result is expressed in ppm the amount of dissolved oxygen needed by the organism to oxidize waste in water. The BOD value does not indicate the actual amount of organic matter, but only in relative terms measures the amount of oxygen needed to oxidize waste in water. If oxygen consumption is high, which is indicated by a smaller amount of dissolved oxygen in the water, the content of the waste material requires high oxygen.

The BOD value of acidic coal mine water in South Kalimantan increased causing the mobilization of organic particles and reduced retention time resulting in fluctuating BOD values [8]. The results of the BOD test in void 1 were $20.34 \mathrm{ppm}$ void 2 of $5.49 \mathrm{ppm}$ and void 3 of $1.37 \mathrm{ppm}$. It also shows that Void 1 has the highest BOD value, so that the degradation process of organic matter has not gone maximal.

\subsection{EC (Electrical Conductivity)}

Electrical conductivity is the ability of water to drain the electric current, which is reflected from the total solids in water and the temperature at the time of measurement. The conductivity of liquid waste in the flow of electric current depends on ion mobility and dissolved content in the waste (inorganic compound $>$ organic cadaver conductor).

Electrical conductivity (EC) was the ability of a liquid to conduct an electric current (also called conductivity). Electrical conductivity in water was a numerical expression that indicates the ability of a solution to conduct an electric current Therefore, the more ionized salt dissolved, the higher the value of electrical conductivity. The value of electrical conductivity depends on the presence of inorganic ions, valence, temperature, and total concentration..

Water with too high electrical conductivity often has a bad taste and high water hardness can cause laxative effects. Other effects of high concentrations of electrical conductivity also affect water clarity, decreased photosynthesis, toxic compounds from the incorporation of heavy metals and an increase in water temperature. [5]. In the measurement of Electrical conductivity in void 1 the value is 1 , void 2 is 1 us and void 3 is 1 us. This shows that the electrical conductivity of the three voids has the same value and is still below the standard quality threshold.

\subsection{TSS (Total Suspended Solid)}

TSS (Total Suspended Solid) or suspended solids are solids that cause water turbidity, are not soluble, and can not precipitate. Suspended solids comprise and particles of a size or weight smaller than that of sediments, such as certain Organic materials, clay and others. On laboratory tests TSS is a solid suspended in a sieve comprising a precipitating part and a non-precipitating part. TSS was a solid that causes turbidity, is not dissolved and does not precipitate directly. That suspended matter has a detrimental effect on water quality because it reduces the penetration of the sun into water bodies, increased turbidity of water that causes 
growth disturbance to producer organisms due to the decline of photosynthesis [1].

The results obtained from TSS analysis that is for samples of acid water ponds of former coal mine on void 1,2 and 3 do not meet quality requirement. For samples of coal acid mine extracts obtained in void 1, void 2 and void 3 respectively of 42 ppm, 320 ppm, $652.67 \mathrm{ppm}$. The characterization test exceeds the allowed quality requirement of $200 \mathrm{ppm}$. Suspended solids in water generally consist of phytoplankton, zooplankton, human waste, animal waste, sludge, plant and animal waste and industrial waste. If water has a high solid value, it will reduce the penetration of sunlight into the water so that the photosynthetic process of the biota will be disrupted [4].

The results of laboratory tests with three samples showed the content of TSS void 1 of 62 ppm, void 2 of $320 \mathrm{ppm}$, and in void 3 of $652.67 \mathrm{ppm}$. Based on visual conditions, liquid waste in void 1 does look quite clear. The low content of TSS padavoid 1, when viewed conditions on the ground, this happens because void 1 does not accept runoff from the coal accumulation area. While void 1 is the oulet pool from the IPAL treatment, where nearby there are plants that function as bioremediation and also phytoremediation that can degrade suspended solution and clear up the liquid wastes present in the pool of the former coal mine. However, the coal is scattered only in small quantities, so that the TSS content contained in the liquid waste coming from void 1 has a very low level. For voids 2 and void 3 , in both pools, TSS parameters have very high levels ranging from $320 \mathrm{ppm}-652.67 \mathrm{ppm}$. according to [15] that suspended solids derived from run-off coal stockpiles are at levels above $2000 \mathrm{ppm}$ even reaching 10,000 ppm. The high levels of TSS in void 2 and void 3 occur because both pools receive runoff water coming from the coal stockpile field. Rainwater that falls in the coal stockpile area brings the fine particles of coal to void 2 and void 3 . The large quantities of coal and rain-borne particles that cause the TSS content in both pools are very high.

\subsection{Iron (Fe)}

Iron is a metal that may be present in waters and sediments with high concentrations. Iron is an important element for living things. Iron is needed by plants and animals at certain concentrations. In animals, iron is very important in oxidation metabolism and a key component in hemoglobin. In plants, iron is an important element in the synthesis of chlorophyll, cytochrome, and nitrogenase enzymes [7]. In plants, iron also plays a role in the enzyme system and the transfer of electrons in the photosynthesis process. However, excessive iron content can inhibit the fixation of other elements [4].

The result of acid wastewater analysis on void coal mine showed iron content in void 1 has a value of 5.408 ppm, void 2 has an iron content of $8.05 \mathrm{ppm}$ and iron content in void of $9.46 \mathrm{ppm}$. High iron content can endanger the life of aquatic microorhanism. Moore in [4] states that $1.0 \mathrm{ppm}$ iron content was considered to endanger the lives of aquatic microorganisms.

\subsection{Manganese (Mn)}

Manganese was a very important nutrient for plants and animals. This metal plays a role in growth and an important component of the enzyme system. Manganese deficiency can lead to stunted growth, as well as the nervous system and reproductive processes become disrupted. In plants, Manganese is an essential element in the metabolic process. [4] states that although manganese are not toxic, manganese can control toxic elements in waters, such as heavy metals. In natural waters, the manganese content is found between 0.1 and 1 ppm. Higher concentrations of manganese can be found in waters with low pH levels [3]. The result of analysis of coal acid liquid waste in coal mine pool showed manganese content in void 1 has value 1.172 ppm, void 2 of $1.25 \mathrm{ppm}$ and manganese void 3 content of $1.24 \mathrm{ppm}$. From the test results are still dangerous to the environment and health, so it needs to be done management and monitoring continuously.

\subsection{Cadmium (Cd)}

The result of analysis of coal acid liquid waste in void coal mine showed cadmium content in void 1 has value 0,011 ppm, void 2 has content of $0,0101 \mathrm{ppm}$ and content in void 3 equal to $0,01006 \mathrm{ppm}$. The result of $\mathrm{Cd}$ content analysis on void 1, 2 and 3 shows not exceed the value of quality standard that has been Decree of State Minister of Environment No. 113 of 2003 is 0.1 ppm [9]. The results of $\mathrm{Cd}$ content analysis on all void content of $\mathrm{Cd}$ does not exceed the value of the quality standard that has been determined Decree of the State Minister of Environment no. 51 of 1995 that is $0.1 \mathrm{ppm}$ [10]. Cd contamination does not exceed the amabng limit because the contaminants have been given dolomite lime ranging from 0.0750-0.0966 mg / kg [18].

\subsection{Liquid Waste Quality Standard}

The coal liquid acid wastes in void 1, 2 and 3 are the former coal mining industry in South Kalimantan. Decree of the State Minister of Environment No. 113 of 2003 on standard quality of coal mining coal waste [9]. Table 2. Comparison of Liquid Waste Quality Standards and Characteristics No Parameters Unit BML void 1, void 2 , and void 3 
Table 2. Comparison of Quality Standards of liquid waste and characteristics

\begin{tabular}{lllllll}
\hline No & $\begin{array}{l}\text { Parame } \\
\text { ter }\end{array}$ & Unit & EQS & Void 1 & Void 2 & Void 3 \\
\cline { 5 - 7 } & & & & & & \\
\hline 1. & pH & - & $6-8$ & 4,01 & 4,50 & 4,75 \\
2. & Temp & ${ }^{0} \mathrm{C}$ & $25-30$ & 25 & 33,9 & 32 \\
3. & Color & NTU & 1 & 3,01 & 0,00 & 0,23 \\
4. & COD & ppm & $100-150$ & 56,50 & 15,69 & 3,92 \\
5. & BOD & ppm & $10-50$ & 20,34 & 5,49 & 1,37 \\
6. & DHL & us & - & 1 & 1 & 1 \\
7. & TSS & ppm & 200 & 62 & 320 & 652, \\
8. & Fe & ppm & 7 & 5,408 & 8,05 & 9,46 \\
9. & Mn & ppm & 4 & 1,172 & 1,25 & 1,24 \\
10. & Cd & ppm & 0,1 & $<0,01$ & $<0,01$ & $<0,01$ \\
& & & & & & \\
\hline
\end{tabular}

Description: EQS = Environmental Quality Standard

In table 2 above can be seen comparison of Liquid Waste Quality Standard specified in Decree of State Minister of Environment no. 113 of 2003 on the standard quality of liquid waste coal mining [9].

Table 2 shows that the characteristics of acid water entering void 1, void 2 and void 3 , for $\mathrm{pH}$ parameters, Temperature, Color, COD, BOD, DHL, TSS, Fe, Mn are still above the standard. As for the content of $\mathrm{Cd}$ was still below the quality standard in accordance with the environmental quality standards specified in the Decree of the Minister of State for Environment no. 113 of 2003 on the Liquid Waste Quality Standard of Coal Mining on the quality standard of liquid waste coal mining activities. However, the government should review the standard of Fe content of $9.46 \mathrm{ppm}$ and is well above 1.0 ppm. according to [4] that $1.0 \mathrm{ppm}$ iron content was considered to endanger the life of aquatic microorganisms. Other heavy metals are Mn also must be managed properly although still not dangerous, but when the accumulation will harm the surrounding environment. The content of TSS reaches a value of $652.67 \mathrm{ppm}$ while the environmental quality standard establishes a TSS content of $200 \mathrm{ppm}$. Thus, the content of TSS in the acidic wastewater of the coal pool is above the established quality standard.

\section{Conclusion}

Acid coal mining in void coal mine has the highest $\mathrm{pH}$ value of 4.01 , the highest temperature is $33.9{ }^{\circ} \mathrm{C}$, the highest Color is 3.01, the highest COD is $56.50 \mathrm{ppm}$, the highest BOD is $20.34 \mathrm{ppm}$, the highest DHL is 1 , the highest TSS of $652.67 \mathrm{ppm}$, the highest $\mathrm{Fe}$ of $9.46 \mathrm{ppm}$, the highest $\mathrm{Mn}$ of $1.72 \mathrm{ppm}$ and the content of $\mathrm{Cd}$ still below the standard set of less than $0.01 \mathrm{ppm}$.

\section{Suggestion}

Processing of acidic wastewater in ponds of former coal mine in South Kalimanta needs to be done. Currently, the processing method using dolomite as absorbent is not optimal so it needs to be done more efficient and environmentally friendly processing.

\section{Acknowledgment}

Ristekdikti as sponsor in research and scientific publications.

\section{References}

1 Agustira, R. Dkk. (2013). Kajian Karakteristik Kimia Air, Fisika Air, Dan Debit Sungai Pada Kawasan Das Padang Akibat Pembuangan Limbah Tapioka. Retrieved From Http://Download.Portalgaruda.Org/Article.

2 Connel, D. W. And Miller, G. J. (1995). Kimia Dan Ekotoksikologi Pencemaran. Ui Press. Jakarta.

3 Dimkic, Heinz-Jurgen, M. (2008). Groundwater Management In Large R iver Basin. Iwa Publishing. London.

4 Effendi. (2003). Telaah Kualitas Air. Penerbit Kanisius. Yogyakarta.

5 F. Z. Ijazah, D. Rohmat, Y. M. (2016). Dampak Aktivitas Penambangan Batubara Terhadap Kualitas Air Sungai Enim Di Kecamatan Lawang Kidul, Kabupaten Muara Enim. Antologi Pendidikan Geografi, Volume 4, Nomor 2, Agustus 2016.

6 Gautama, R. S. (2014). Pembentukan, Pengendalian Dan Pengolahan Air Asam Tambang. Itb: Bandung.

7 Kadlec, Robert H., S. D. W. (2009). Treatment Wetlands. Second Edition. Crc Press. New York.

8 Karathanasis, A. D., Potter, C. L. \& Coyne, M. S. (2003). Vegetation Effects On Fecal Bacteria, Bod, And Suspended Solid Removal In Constructed Wetlands Treating Domestic Wastewater. Ecological Engineering 20, ., 157-169.

9 Keputusan Menteri Negara Lingkungan hidup no. 113 Tahun 2003 tentang Baku Mutu Limbah Cair Pertambangan Batubara.

10 Keputusan Menteri Negara Lingkungan Hidup no. 51 Tahun 1995

11 Kristanto, P. (2004). Ekologi Industri. Surabaya: Andi Offset. Surabaya.

12 Liu, H. F. D, L. B. G. (1999). Environmental Engineer's Handbook. Crc Press. Usa.

13 Marganingrum, D., \& Noviardi, R. (2010). Pencemaran Air Dan Tanah Di Kawasan Pertambangan Batubara Di Pt . Berau Coal, Dyah Marganingrum Dan Rhazista Noviardi, 20(1), 11 20.

14 Nurisman, E, 2012. Studi Terhadap Dosis Penggunaan Kapur Tohor (Cao) Pada Proses Pengolahan Air Asam Tambang Pada Kolam Pengendap Lumpur Tambang Air Laya Pt. Bukit Asam (Persero), Tbk. 
15 Plaffin, J. And Z. (2006). Encyclopedia Of Environmental Science \& Engineering. Crc Press. Usa.

16 Salmin. (2005). Oksigen Terlarut (Do) Dan Kebutuhan Oksigen Biologi (Bod) Sebagai Salah Satu Indikator Untuk Menentukan Kualitas Perairan. Oseana., $X x x(3): 21$.

17 Smethurst.G, B. . C. K. M. (2002). Basic Water Treatmen. Third Edition.Rsc Press. Cambridge Uk.
18 Susana, R. (2011). Ketersediaan Cd, Gejala Toksisitas Dan Pertumbuhan 3 Spesies Brassicaceae Pada Media Gambut Yang Dikontaminasi Kadmium (Cd). Jurnal Tek. Perkebunan \& Psdl. 1: 9-16.

19 Yuliastuti, E. (2011). Kajian Kualitas Air Sungai Ngringo Karanganyar Dalam Upayah Pengendalian Pencemaran. Retrieved From Https://Core.Ac.Uk/Download/Files/379/11730710. Pdf 